\title{
Karachun V. \\ REPRODUCING OF SECURITY AND LIMITED VISIBILITY OF FIRE WEAPONS OF DEFENCE LINE FROM AERIAL RECONNAISSANCE
}

Проаналізовано можливість технічної реалізачії маскування вогневих засобів польової фортифікаиії відкритого типу від повітряної розвідки. Доведено, що скритність і обмежена примітність бойової техніки може бути забезпечена шляхом штучного формування поверхні перешкоди засобам пошуку у вигляді зон каустики в рідинній частині ииліндричного модуля маскувального тунелю. Окреслені умови формування поверхні перешкоди засобам локащії.

Ключові слова: хвильовий розмір, аберація, зона каустики, хвильове співпадання.

\section{Introduction}

The role of camouflage in enhancing combat effectiveness of fortifications is sufficiently large and decisive. Vitality of fortified positions after artillery preparation will generally depend on the fire degree of enemy into positions. Effectiveness of fire action for the most part depends on the data completeness of aerial reconnaissance of the enemy. The greatest damage of positions and troops brings aimed fire when the opponent has the exact deployment of positions, military equipment, manpower and clearly marked signs and visibility of field fortifications.

Especially dangerous is the direct fire of guns and anti-tank guided missiles (ATGM) for clearly outlined visible targets.

The main task is outlined - the most difficult detection and delineation of visibility of defensive means for intelligence. This, in turn, provides enemy suddenness of fire weapon employment in position. Following the famous statement «...Surprise - means defeat...» a solid foundation for victory will be laid.

Camouflage is a crucial tool to mislead the enemy and victorious march factor.

It is paid special attention to the problem of security of armored vehicles from the means of direct and echolocation in a combat zone. Solution of this problem on the front line enables such deployment of weapons when generating unexpected eruption of fire strength and attacking strike of force operations through its surprise will enable effective use of firepower, armor and fire weapon force for victory. This problem is relevant in the military conflicts, especially in asymmetric warfare.

\section{The object of research and its technological audit}

The object of the research is a process of an elastic interaction of ultrasound beam with a cylindrical module in the form of two circular shells with same length coaxially connected to their ends. Sealed gap between two circular shells is filled with fluid.

Outside irradiation by the ultrasonic beam affects the properties of the module, including the emergence of local characteristics of the outer shell, and to change energy state of liquid-static gap between shells.

It is great interest in the applied use of these changes for echolocation tasks in terms of artificial formation of «acoustic transparency» situation.

Simulation model of the studied phenomenon belongs to the technical means of camouflage of the fire military equipment, namely the camouflage of field fortification such as trenches for tanks with a limited sector of fire. It is necessary to assess the degree of security and limited visibility of fire weapon of the defense line positions against aerial reconnaissance of the enemy.

\section{The aim and objectives of research}

The aim of research is search of artificial camouflage of armored vehicles in terms of fighting in local military conflicts from the means of aerial reconnaissance.

To achieve this aim it is necessary to perform the following objectives:

1. Calculate the sound transmission of outer shell of the tunnel and identify the possibility of manifestation of the wave coincidence between acoustic beam and vibration of the surface of cylindrical module.

2. Analyze the potential of wave coincidence in the shell.

\section{Research of existing solutions of the problem}

Time is inevitably sets some priorities to create means of defense and external intelligence. The projects of cruise missiles, suborbital and atmospheric hypersonic technologies of different functions and other are developed along with ballistic missiles [1]. However, ground means of defense aren't lose their positions - fighting vehicles (tanks), antiaircraft guns, different mortar means, self-propelled artillery, kamikaze robots and so on. Having enough longer land border, Ukraine traditionally pays great attention to the development and improvement of armored forces as one of the most effective means of defense [2].

Therefore, the role of this type of arms for the government is difficult to overestimate. However, it should be 
noted that with the appearance of modern means of destruction, a lone tank becomes a vulnerable target. Especially, this aspect is important in the conditions of long-range battle $-3 \mathrm{~km}$ length, when combat machine is unable to timely detect anti-tank weapons of the enemy, on the one hand, and spending a lot of time in the collection, processing and transmission of navigational information in the control system- on the other. Efficiency of enemy defeat increases significantly using combination of two operations - fire and motion maneuver (along the front and in depth). The first is to concentrate fire of several fighting machines on the combat target, the second is the movement control of military units or departments as a whole, based on comprehensive, complete information about the target designation for tanks, performing combat tasks. It aims to identify and classification of the target by commander, transmission of this information to subordinate vehicle and finally find and identify targets by executive operator. The hazard level of modern anti-tank weapons is such that they must be neutralized no more than 10-20 seconds from the time of their discovery [3]. Thus, the problem of absolute camouflage of armored vehicles seems one of the most important components of combat support and resolve it appears extremely important [4-7].

The emergence and development of armored vehicles that can protect crew and support subdivisions by friendly fire led to the creation and improvement of anti-tank weapons and other similar weapons. As a result, a wealth of new protection facilities was developed over the last decades. So, before the tanks were enough only armor that protects from bullets and shrapnel, and modern military equipment can't always have just armored body and require additional protection facilities.

Simple mimetic camouflage was created - an elastic polymer that replicates the ability of squid and octopus skin, changing its color and texture of the surface. Camouflage of this elastomer can hide a soldier or armored vehicle in any situation. A team of scientists from MIT and Duke University has developed a new flexible electroactive polymer with unique properties [8]. Under the influence of an electric current the material changes its color and texture that is ideal camouflage, able to conceal the silhouette of a soldier on a different background. Except camouflage, the polymer can be used for protection of military equipment against fouling and for new type of video screens. Unlike similar camouflage technologies, elastomeric camouflage doesn't use expensive and fragile screen can be made widely of available raw materials and using standard production processes.

The current version of the polymer can reproduce a limited range of colors and textures, but according to the developers, the number of options for coloring can be increased. The principle of the camouflage is based on the phenomenon of polymer deformation under the influence of an electric current. This phenomenon was discovered in 2011 [8]. Deformation of the elastomer activates mechanically sensitive specific molecules embedded in polymer. They make camouflage light up or change a color. Elastomeric camouflage has one drawback: each type of elastomer can only repeat one pattern of texture and color. In other words, to create a full chameleon-like camouflage it is necessary to «sew» the different types of elastomer. Currently, scientists are working on a cheap and simple solution to this problem [8].
Industry and military experts understood that armor alone is unlikely to provide protection against all threats. The result was the emergence of new additional systems. In recent decades, many theoretical studies were conducted. As recent examples there are some of the results of the American program FCS (Future Combat Systems). The result of one FCS research program is Survivability Onion or Onion Skin concept. This concept involves the division of protection of armored vehicles for six conventional «layers»: Avoid Encounter, Avoid Detection, Avoid Acquisition, Avoid Hit, Avoid Penetration and Avoid Kill. Each of them concerns different points of attack of the enemy and involves the use of specific systems intended to prevent certain enemy action. «Onion Skin» concept implies avoid meeting with the enemy, preventing of equipment identification by them and, if necessary, the failure of its attack, as before firing as well as at the time of entering enemy ammunition. Finally, measures to improve the survivability of armored vehicles even in case of defeat are provided. The proposed division on six levels of protection layers have a great interest as regards the various processes faced by armored vehicles, and can offer the solution of the tasks [9-11].

\section{Methods of research}

The data from scientific papers [12-17] is used for this research.

The following research methods are used: methods of construction of fencing structures, methods of radiation acoustics and methods of hydroacoustics.

The studied construction is belong to the field of armaments, including the technical means of firing military equipment camouflage, namely field fortification camouflage such as open trenches for tanks with a limited sector of fire. This construction can be used to required security and limited visibility of fire weapons of defense line positions against aerial reconnaissance of the enemy.

This trench construction for the tank with a limited sector of fire includes pit, ramp and parapet [15] (Fig. 1). Pit is covered by a cylindrical tunnel with a separate, tightly interconnected by the ends, identical cylindrical modules in the form of two shells connected coaxially on their ends by the flat rings, and sealed gap between shells is filled with fluid. The lower surface of the tunnel is embedded in soil under the pit. The upper surface of the tunnel is protected by the parapet and is irradiated by ultrasonic beam of given frequency. Further, it is necessary to artificially create circular waves at frequencies below the limit $f_{\text {lim }}$ in the sound-transmitting surface of the outer shell [16].

If to form the wave size of the outer shell is much greater than one, i. e. to perform inequality:

$$
1 \ll k R,
$$

where $k=\omega / c$ - wave number; $R$ - radius of the outer shell; $c$ - sound velocity in the liquid; $\omega$ - angular frequency of ultrasonic radiation, then shell element can be considered as a flat, which will emit a sound wave into the liquid at an angle $\alpha$ to the velocity $V$ of circular wave of the outer shell $-\sin \alpha=c_{0} / V$ [4].

Using the methods of ray acoustics, it can identify the cause of the formation of caustic surface in the liquid 
due to the current aberration (lat. - aberratio) of sound waves emitted by the outer shell in the fluid [17]. This phenomenon will lead to concentration of sound energy in the liquid and forms a cylindrical caustic surface confocal to the inner surface of the outer shell. It artificially creates the surface of high energy in the liquid. It remains to direct the beam of ultrasonic radiation to the surface of the outer shell at coincidence angle and form a resonance situation when it comes spatial (geometric resonance or wave coincidence) resonance. The ultrasonic beam will pass through the shell without dissipation of energy of sound waves [16] and flow into the liquid without loss of energy. Thus, the outer shell will be «acoustically transparent».
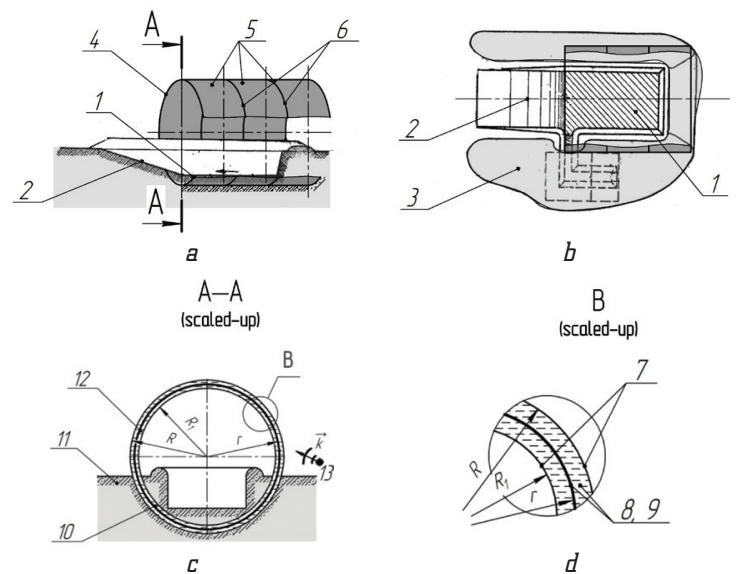

Fig. 1. The tank trench with a limited sector of the fire: $a-$ in longitudinal section, under the camouflage tunnel; $b$ - in longitudinal section, with camouflage tunnel; $c$ - the cross-section, in camouflage tunnel; $d$ - sealed, fluid-filled gap between the outer and inner shells of the tunnel, scaled-up

In Fig. 1: 1 - pit; 2 - parapet; 3 - ramp; 4 - cylindrical tunnel; 5 - cylindrical tunnel module; 6 - rigidly interconnected ends of the module; 7 - two shells of equal length, each of radius $R$ and $R_{1} ; 8$ - sealed gap between the shells; 9 - liquid; 10 - the lower surface of the tunnel; 11 - soil; 12 - the upper surface of the tunnel; 13 ultrasonic beam; $\vec{k}$ - wave vector of a given frequency.

The source of the acoustic emission of the test bench is industrial ultrasound plant УЗП-6-1 (Ukraine): power $300 \mathrm{~W}$ and radiation frequency $-42 \mathrm{kHz}$.

For the convenience of the studied phenomenon, glass membranes were selected (Fig. 2) (sound velocity $\left(c_{o}=1497 \mathrm{~ms}^{-1}\right)$ and a liquid in inter-shell space is normal drinking water $\left(V=5370 \mathrm{~ms}^{-1}\right)$.

The radius of the outer shell is $R=22,5 \mathrm{~mm}$, and the radius of the inner shell is $R_{1}=18,5 \mathrm{~mm}$.

Wave size is:

$$
k R=\frac{\omega}{c_{a} R}=35,41 \cdot 10^{3},
$$

where $c_{a}=331 \mathrm{~m} / \mathrm{s}-$ sound velocity in the air. Thus, the requirement $1 \ll k R$ is fulfilled for the value of the wave size of the outer shell.

\section{Research results}

Thus, the inner surface of the outer shell will emit the sound waves at an angle $\alpha$ into the liquid. Aberration of the sound waves are observed in the liquid and made at an angle [17]:

$$
\sin \alpha=\frac{c_{R}}{V}=0,278
$$

so $\alpha=16^{\circ} 10^{\prime}$.

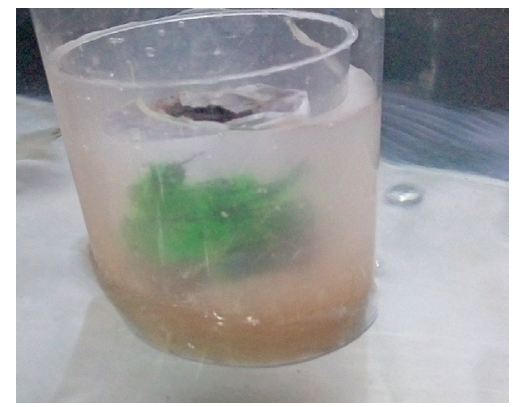

Fig. 2. Design of test bench without the influence of ultrasound

Thus, the radius of the caustic surface in the form of cylindrical surface coaxial with the inner surface of the outer shell will be equal to:

$r=R \cos \alpha=21,53 \mathrm{~mm}$.

Artificially generated caustic surface is the spatial distribution of zones of high energy fluid and significant turbulence. This zone will block the rays of echolocation means and sensors will indicate a blurred patch (Fig. 3). Increasing power of ultrasonic radiation, we can adjust the degree of disappearance of clear contours of the object that is in the middle of the inner shell (Fig. 3).

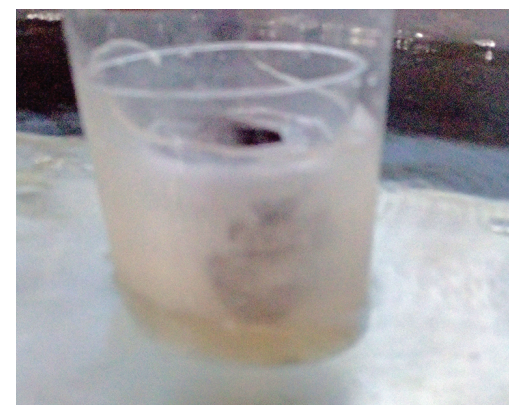

Fig. 3. Artificial formation of security and limited visibility of the object in the middle of the inner shell

This effect can be enhanced also by changing the properties of the liquid in the inter-shell space by correcting the structure of the liquid, so as to reduce to the maximum absorption (or reflection) of echolocation rays.

\section{SWOT analysis of research results}

Strengths. Thickness of caustic zone increases significantly if artificial irradiation by УЗП-6-1 (Ukraine) unit is carried out at an angle of 6 degrees 30 minutes that is the point of wave coincidence of incident waves and angular wave of outer shell. [16] Under these conditions, the surface of the outer shell becomes «acoustically transparent» and irradiation is carried out without energy 
dissipation. This creates advantages of security and limited visibility of military equipment.

Weaknesses. Weakness of research is the complexity of assembling the module components of camouflage tunnel.

Opportunities. Opportunity of further research is the analysis of optimal consolidation of the solid shells with the liquid-phase gap between them.

Threats. Existing facilities of the manufacturers are reduced to a degree of camouflage in the ground through various means and technical solutions, which basically decide whether the optical limitations of classification and detection of armored vehicles. In the public media analogue of the proposed technical solution to problems of fire weapons camouflage in conditions of open field fortification isn't covered.

\section{Conclusions}

1. Numerical analysis of shell sound transmission is made for laboratory research of the model. Conditions of «acoustic transparency» appearance of the outer shell are identified. They have a satisfactory coincidence with the conditions of laboratory research of the model.

2. The possibility of artificially creation of resonance phenomenon in the form of wave coincidence and the aberration emergence of emitted outer shells into the liquid of sound waves in the double-shell system is proved. Aberration generates the formation of zones of increased energetic state of the liquid - caustic zone.

Caustic zone, which is formed artificially by ultrasound, will block echolocation means and make invisible military equipment of open field fortifications.

It is found that thickness of caustic zone will increase if artificial irradiation by УЗП-6-1 (Ukraine) unit to perform at an angle of 6 degrees 30 minutes, that is the point of coincidence of the wave incident waves and angular waves of outer shell [16]. Under these conditions, the surface of the outer shell becomes «acoustically transparent» and irradiation is carried out without energy dissipation.

\section{References}

1. Karachun, V. The Additional Error of Inertial Sensors Induced by Hypersonic Flight Conditions [Text] / V. Karachun, V. Mel'nick, I. Korobiichuk, M. Nowicki, R. Szewczyk, S. Kobzar // Sensors. - 2016. - Vol. 16, № 3. - P. 299 doi:10.3390/s16030299

2. Bondariev, I. H. Evoliutsiia vitchyznianykh system aktyvnoho zakhystu bronetankovoi tekhniky. Napriamy udoskonalennia y rozvytku [Text] / I. H. Bondariev, M. V. Kolomiiets // Perspektyvy rozvytku ozbroiennia ta viiskovoi tekhniky Sukhoputnykh viisk. Zbirnyk tez dopovidei Mizhnarodnoi naukovotekhnichnoi konferentsii (Lviv, 18-20 travnia 2016 r.). - Lviv: NASV, 2016. - P. 16

3. Kazan, P. I. Osnovni napriamy udoskonalennia systemy otsiniuvannia operatyvnykh (boiovykh) spromozhnostei viiskovykh chastyn (pidrozdiliv) Sukhoputnykh viisk zbroinykh syl Ukrainy [Text] / P. I. Kazan, M. H. Ivanytskyi // Perspektyvy rozvytku ozbroiennia ta viiskovoi tekhniky Sukhoputnykh viisk. Zbirnyk tez dopovidei Mizhnarodnoi naukovo-tekhnichnoi konferentsii (Lviv, 18-20 travnia 2016 r.). - Lviv: NASV, 2016. P. 37-38.

4. Mel'nick, V. N. Acoustic impedance of inercial navigator and mistakes outside target-determination manoeuvre on march [Text] V. N. Mel'nick, V. V. Karachun, G. V. Boiko // Aviatsionnokosmicheskaia tehnika i tehnologiia. - 2013. - № 5. - P. 50-60.
5. Mel'nick, V. Volnovye zadachi v akusticheskih sredah [Text] Monograph / V. Mel'nick, N. Ladogubets; National Technical University of Ukraine «Igor Sikorsky Kyiv Polytechnic Institute», National Aviation University. - Kyiv: Korneichuk, 2016. - 432 p.

6. Karachun, V. V. Zadachi suprovodu ta maskuvannia rukhomykh obiektiv [Text]: Monograph / V. V. Karachun, V. N. Mel'nick; National Technical University of Ukraine «Kyiv Polytechnic Institute». - Kyiv: Korniichuk, 2011. - 264 p.

7. Mel'nick, V. Additional errors of autonomous azimuthal positioning of fighting machines [Text] / V. Mel'nick, V. Karachun // Eastern-European Journal Of Enterprise Technologies. 2012. - № $2 / 7$ (56). - P. 4-7. - Available at: \www/URL: http://journals.uran.ua/eejet/article/view/3749

8. Uchenye sozdali prostoi mimikriruiushchii kamufliazh [Electronic resource] // ZOOM.CNews. - 17.09.2014. - Available at: \www/URL: http://zoom.cnews.ru/rnd/article/item/ uchenye_sozdali_prostoj_mimikriruyushchij. - 19.01.2016.

9. Brone Sait [Electronic resource]. - 1999. - Available at: \www/ URL: http://armor.kiev.ua/. - 19.01.2016.

10. GlobalSecurity.org [Electronic resource]. - 2000. - Available at: \www/URL: http://globalsecurity.org/. - 19.01.2016.

11. Defense-Update [Electronic resource]. - 2002. - Available at: Iwww/URL: http://defense-update.com/. - 19.01.2016.

12. Gitin, A. V. Legendre transformation: Connection between transverse aberration of an optical system and its caustic [Text] / A. V. Gitin // Optics Communications. - 2008. - Vol. 281, № 11. - P. 3062-3066. doi:10.1016/j.optcom.2008.02.003

13. Rose, H. Outline of an ultracorrector compensating for all primary chromatic and geometrical aberrations of charged-particle lenses [Text] / H. Rose // Nuclear Instruments and Methods in Physics Research Section A: Accelerators, Spectrometers, Detectors and Associated Equipment. - 2004. - Vol. 519, № 1-2. - P. 12-27. doi:10.1016/j.nima.2003.11.115

14. Kimoto, K. Practical procedure for coma-free alignment using caustic figure [Text] / K. Kimoto, K. Ishizuka, N. Tanaka, Y. Matsui // Ultramicroscopy. - 2003. - Vol. 96, № 2. P. 219-227. doi:10.1016/s0304-3991(03)00020-2

15. Ermolaev, A. A. Voiskovye fortifikatsionnye sooruzheniia [Text] Practical Guide / A. A. Ermolaev. - Moscow: Voennoe izdatel'stvo, 1984. - 375 p.

16. Zaborov, V. I. Teoriia zvukoizoliatsii ograzhdaiushchih konstruktsii [Text]: Monograph / V. I. Zaborov. - Moscow: Izdatel'stvo literatury po stroitel'stvu, 1969. - 187 p.

17. Shenderov, E. L. Volnovye zadachi gidroakustiki [Text] Monograph / E. L. Shenderov. - Leningrad: Sudostroenie, 1972. - 352 p.

\section{ВОСПРОКЗВЕДЕНИЕ СКРЫТНОСТИ И ОГРАНКЧЕННОЙ ПРИМЕТНОСТИ ОГНЕВЫХ СРЕДСТВ ЛИНИИ ОБОРОНЫ ОТ ВОЗДУШНОЙ РАЗВЕДКИ}

Проанализирована возможность технической реализации маскировки огневых средств полевой фортификации открытого типа от воздушной разведки. Доказано, что скрытность и ограниченная примечательность боевой техники может быть обеспечена путем искусственного формирования поверхности препятствия средствам поиска в виде зон каустики в жидкостной части цилиндрического модуля маскировочного тоннеля. Очерчены условия формирования поверхности защиты от локационного луча.

Ключевые слова: волновой размер, аберрация, зона каустики, волновое совпадение.

Karachun Volodimir, Doctor of Technical Sciences, Professor, Department of Biotechnics and Engineering, National Technical University of Ukraine «Igor Sikorsky Kyiv Polytechnic Institute», Ukraine, e-mail: karachun11@i.ua, ORCID: http://orcid.org/00000002-6080-4102 